\title{
Penicillinase producing gonococci: a spent force?
}

\author{
C A ISON,* J GEDNEY,* J R W HARRIS, † AND C S F EASMON*
}

From the Departments of ${ }^{*}$ Medical Microbiology and $\dagger$ Venereology, Wright Fleming Institute, St Mary's Hospital Medical School, London

SUMMARY Though the incidence of gonorrhoea caused by penicillinase producing Neisseria gonorrhoeae (PPNG) strains at St Mary's Hospital rose rapidly from 1980 to reach 6.2\% in 1982, it declined in $1983(8.6 \%)$ and in $1984(6.5 \%)$, a trend that has continued in 1985 . The use of penicillinase stable antibiotics or more effective contact tracing are unlikely to be responsible for this recent decline. We have always isolated very few PPNG strains from homosexual men, and the possible effects of the acquired immune deficiency syndrome (AIDS) on sexual behaviour in this group is therefore unlikely to be relevant.

We have seen a steady increase in the proportion of PPNG strains carrying the 4.4 megadalton penicillinase plasmid (67\% of PPNG strains in 1984). Strains carrying both the 4.4 megadalton plasmid and the 24.5 megadalton conjugal plasmid were very common in 1982, but since then have declined in importance. PPNG strains carrying the 3.2 megadalton plasmid have become less common, and the presence of the 24.5 megadalton plasmid in these strains has not apparently led to their wider dissemination in the community. Whereas the basic pattern of PPNG auxotypes has changed little, since 1982 we have isolated an increasing number of mixed auxotypes with nutritional requirements other than just proline. PPNG strains carrying the 4.4 megadalton plasmid seem to be more resistant to erythromycin, tetracycline, and streptomycin than those carrying the $3 \cdot 2$ megadalton plasmid. Spectinomycin resistance has only occured in strains carrying the 4.4 megadalton plasmid.

\section{Introduction}

Pencillinase producing Neisseria gonorrhoeae (PPNG) strains were first reported in 1976. ${ }^{2}$ PPNG strains produce a TEM-1 type $\beta$ lactamase, ${ }^{3}$ which is coded on a plasmid of either 3.2 or 4.4 megadaltons. ${ }^{4}$ These strains are believed to have originated in South East Asia and Africa as two separate but related clones. ${ }^{5}$ Despite their relatedness, PPNG strains from the two different geographical areas were shown to have distinct properties. Isolates from South East Asia carried a 4.4 megadalton penicillinase coding plasmid (often in combination with the 24.5 megadalton conjugal plasmid), were either prototrophic or required proline for growth, and were moderately resistant to antibiotics. ${ }^{56}$ In contrast, isolates from Africa carried a 3.2 megadalton penicillinase coding plasmid without the 24.5 megadalton plasmid generally required arginine for growth and were more sensitive to antibiotics. $^{5}$

Address for reprints: Professor C S F Easmon, Department of Medical Microbiology, Wright Fleming Institute, St Mary's Hospital Medical School, London W2 1 PG

Accepted for publication 23 December 1985
Between 1976 and 1982 there was a steady increase in PPNG infections in the United Kingdom with evidence of endemic transmission during 1981 and 1982.' At the Praed Street Clinic, St Mary's Hospital, we isolate an appreciable proportion of PPNG strains isolated in the United Kingdom. In recent years this proportion has been as high as $20 \%$. We report here our experiences with PPNG strains between 1978 and 1984.

\section{Methods}

ISOLATION

All strains of PPNG were isolated from patients attending the sexually transmitted diseases (STD) clinic at St Mary's Hospital. Urethral, cervical, and rectal samples were cultured directly on to neisserial isolation medium containing $36 \mathrm{~g} / 1$ gonococcal (GC) agar base (Difco) supplemented with $1 \%$ IsoVitalex (BBL) and made selective by the addition of vancomycin, colistin, trimethoprim, and amphotericin. The plates were stored at $36^{\circ} \mathrm{C}$ in $7 \%$ carbon dioxide until transported to the laboratory where they were reincubated for 48 hours.

$N$ gonorrhoeae organisms were identified as Gram 
negative, oxidase positive cocci that utilised glucose but not maltose or sucrose and did not produce $\beta$ galactosidase. The ability to produce penicillinase was detected using Nitrocefin (chromogenic cephalosporin). ${ }^{8}$ All strains of PPNG were maintained on GC agar base with $1 \%$ IsoVitalex and $1 \mathrm{mg} / 1$ penicillin, susperided in $10 \%$ glycerol broth, and stored in liquid nitrogen.

\section{PLASMID CONTENT}

Each strain was grown overnight on one GC agar plate containing penicillin. The growth was harvested in saline and collected by centrifugation. Plasmids were extracted using the rapid method of Birnboim and Doly, ${ }^{9}$ electrophoresed in $1 \%$ agarose (Sigma) in $20 \mathrm{mmol} / 1$ sodium acetate buffer, $\mathrm{pH} 7 \cdot 8$, and visualised using ethidium bromide $(1 \mathrm{mg} / \mathrm{l})$.

\section{AUXOTYPE}

All strains were suspended in saline, and $1 \mu$ l volumes were inoculated on to chemically defined media as described by Catlin ${ }^{10}$ using a multipoint inoculator (Denley). After incubation at $36^{\circ} \mathrm{C}$ in $7 \%$ carbon dioxide for $\mathbf{4 8}$ hours, the plates were examined for the presence of macrocolonies. Media lacking cysteine, proline, arginine, arginine but with the addition of ornithine, methionine, hypoxanthine, and vitamins were used as well as a complete medium.

\section{SUSCEPTIBILITY TO ANTIBIOTICS}

A suspension of each strain was made from an overnight culture on $\mathrm{GC}$ agar with penicillin at $36^{\circ} \mathrm{C}$ in $7 \%$ carbon dioxide. After vortexing to disperse clumps, the optical density was adjusted to $1.0(\lambda 540 \mathrm{nms})$ giving $0.5-1.0 \times 10^{8}$ colony forming units (cfu) $/ \mathrm{ml}$. Volumes of $1 \mu \mathrm{l}\left(10^{5} \mathrm{cfu}\right)$ were inoculated on to agar plates containing diagnostic sensitivity test (DST) agar with $5 \%$ lysed horse blood, $1 \%$ IsoVitalex, and the appropriate dilution of antibiotic. After incubation for $\mathbf{4 8}$ hours at $36^{\circ} \mathrm{C}$ in $7 \%$ carbon dioxide, the point of complete inhibition of growth was noted as the minimum inhibitory concentration (MIC). Four antibiotics were tested: tetracycline $(0.5-8 \mathrm{mg} / \mathrm{l})$, streptomycin (8-64 mg/l), erythromycin (0.06-4 mg/l), and low levels of resistance to spectinomycin using small step dilutions between $8 \mathrm{mg} / 1$ and $40 \mathrm{mg} / \mathrm{l}$.

\section{Results}

Table I shows the yearly total numbers of PPNG isolates in 1978-84. These are also expressed as a percentage of all gonococci isolated each year at $\mathrm{St}$ Mary's Hospital and of the total PPNG isolates reported nationally. The main rate of increase in the proportion of PPNG strains occurred in 1981 and 1982 at $2 \cdot 7$ times and $3 \cdot 2$ times that of the previous
TABLE I Penicillinase producing Neisseria gonorrhoeae (PPNG) isolated at St Mary's Hospital 1978-84

\begin{tabular}{lrll}
\hline Year & No & $\begin{array}{l}\text { \% of gonococci } \\
\text { at St Mary's }\end{array}$ & $\begin{array}{l}\text { \% of PPNG strains } \\
\text { reported nationally }\end{array}$ \\
\hline 1978 & 3 & 0.12 & 10.0 \\
1979 & 12 & 0.33 & 11.5 \\
1980 & 25 & 0.7 & 11.8 \\
1981 & 57 & 1.9 & 12.9 \\
1982 & 212 & 6.2 & 20.5 \\
1983 & 277 & 8.6 & 22.6 \\
1984 & 192 & 6.5 & $*$ \\
\hline
\end{tabular}

* Final figure not yet published

TABLE II Gonococci isolated from men 1978-84

\begin{tabular}{|c|c|c|c|c|}
\hline \multirow[b]{2}{*}{ Year } & \multicolumn{2}{|c|}{ Isolates of gonococci: } & \multicolumn{2}{|c|}{ Isolates of PPNG strains: } \\
\hline & Total & From men & From men & $\begin{array}{l}\text { From homosexual } \\
\text { men } \\
\text { (rectal isolates) }\end{array}$ \\
\hline $\begin{array}{l}1978 \\
1979 \\
1980 \\
1981 \\
1982 \\
1983 \\
1984\end{array}$ & $\begin{array}{l}2486 \\
3685 \\
3670 \\
2992 \\
3403 \\
3210 \\
2932\end{array}$ & $\begin{array}{l}1291 \\
2417 \\
2439 \\
2027 \\
2302 \\
2313 \\
2090\end{array}$ & $\begin{array}{r}2 \\
9 \\
17 \\
40 \\
116 \\
153 \\
136\end{array}$ & $\begin{array}{l}0 \\
0 \\
0 \\
0 \\
3(1) \\
11(4) \\
10(4)\end{array}$ \\
\hline
\end{tabular}

PPNG = penicillinase producing Neisseria gonorrhoeae.

year, respectively. If this trend had continued in 1983 we would have seen an incidence of PPNG strains of between $15 \%$ and $18 \%$. The actual figure of $8.3 \%$ therefore represented a pronounced slowing of the rate of increase of PPNG strains. In 1984 the number of PPNG strains isolated fell to $192(6.5 \%$ of all gonococcal isolates), and in the first six months of 1985 only $40(3.4 \%)$ PPNG strains were isolated.

Despite the predominance of infections in men, only 24/778 PPNG strains were isolated from male homosexuals. Of these a mere nine were rectal isolates (table II).

\section{PLASMID CONTENT}

The plasmid content of 605 of these strains of PPNG was measured, as $10-15 \%$ of strains were not available for testing for each year. All PPNG strains tested carried the 2.6 megadalton cryptic plasmid. Before 1980 we isolated only 15 PPNG strains. Seven carried the 3.2 megadalton penicillinase coding plasmid, five carried the 4.4 megadalton penicillinase coding plasmid in conjunction with the 24.5 megadalton conjugal plasmid, and three were not tested. Twenty four strains were isolated in $1980,14(58 \%)$ of which carried the $3 \cdot 2$ megadalton plasmid. In 1980 to 1984 
there was a decrease in the percentage of PPNG strains carrying the 3.2 megadalton plasmid and an increase in strains carrying the $\mathbf{4 . 4}$ megadalton plasmid, which in 1984 reached $67 \%$ of PPNG strains isolated (table III). Of the PPNG strains that carried the 4.4 megadalton plasmid, the numbers also carrying the 24.5 megadalton conjugal plasmid reached a peak of $38 \%$ of all PPNG strains isolated in 1982 . This has decreased to only $12 \%$ in 1984 . The rise in the proportion of PPNG strains carrying the 4.4 megadalton plasmid alone was gradual during the latter part of 1983, but the high level of more than $60 \%$ of PPNG strains carrying a 4.4 megadalton plasmid with or without the 24.5 megadalton plasmid (more than half of all PPNG strains isolated) was maintained throughout 1984 . Strains carrying the $3 \cdot 2$ megadalton plasmid together with the 24.5 megadalton plasmid were first isolated in 1980 , and have remained at a low level (3\% of PPNG strains in 1984). plasmid as well were either wild type $(50.3 \%)$ or proline requiring $(41 \cdot 4 \%)$. Though there were some yearly variations, these did not affect appreciably the distribution of auxotype in relation to plasmid content. Strains requiring both proline and arginine were first encountered in 1981 and we have since isolated 23 such strains, of which 16 carried the $3 \cdot 2$ megadalton plasmid alone.

Since 1982 we have isolated strains of PPNG that require proline for growth but have additional requirements, such as hypoxanthine and uracil (table V). These "mixed" auxotypes have occurred in strains carrying either the 3.2 or the 4.4 megadalton plasmid, but are no more common in PPNG strains carrying the conjugal plasmid. Four other auxotypes have been isolated: those requiring arginine and uracil; requiring uracil alone; requiring arginine, hypoxanthine, and uracil; and requiring methionine, but the numbers of these isolates were low.

TABLE III Incidence of different plasmid types in penicillinase producing Neisseria gonorrhoeae (PPNG) strains isolated at St Mary's Hospital, London 1980-4

\begin{tabular}{|c|c|c|c|c|c|c|}
\hline \multirow[b]{2}{*}{ Year } & \multirow[b]{2}{*}{ No isolated } & \multirow[b]{2}{*}{ No (\%) not tested } & \multicolumn{4}{|c|}{ No (\%) with plasmid type (megadaltons) } \\
\hline & & & $3 \cdot 2$ & $3 \cdot 2+24 \cdot 5$ & 4.4 & $4 \cdot 4+24.5$ \\
\hline $\begin{array}{l}1980 \\
1981 \\
1982 \\
1983 \\
1984\end{array}$ & $\begin{array}{r}24 \\
56 \\
180 \\
266 \\
186\end{array}$ & $\begin{array}{r}2(8) \\
10(18) \\
29(16) \\
38(14) \\
28(15)\end{array}$ & $\begin{array}{l}11(46) \\
17(30) \\
41(23) \\
49(18) \\
27(15)\end{array}$ & $\begin{array}{r}3(13) \\
6(11) \\
4(2) \\
12(5) \\
6 \quad(3)\end{array}$ & $\begin{array}{r}3(13) \\
16(29) \\
38(21) \\
102(38) \\
103(55)\end{array}$ & $\begin{array}{r}5(21) \\
7(13) \\
68(38) \\
65(24) \\
22(12)\end{array}$ \\
\hline
\end{tabular}

AUXOTYPE

Most of the 569 PPNG strains on which auxotyping was performed belonged to one of three auxotypes; wild type (or prototrophic), proline requiring, or arginine requiring (table IV). Strains carrying the $3 \cdot 2$ megadalton plasmid with or without the 24.5 megadalton plasmid were equally divided between all three auxotypes. Strains carrying the 4.4 megadalton plasmid alone were predominately proline requiring (82\%), whereas strains carrying the 24.5 megadalton

TABLE IV Plasmid content of main PPNG auxotype. Figures are numbers of isolates (\% of each plasmid type)

\begin{tabular}{lllll}
\hline \multicolumn{5}{l}{ Plasmid content (megadaltons): } \\
\cline { 2 - 5 } Auxotype $^{*}$ & $3 \cdot 2$ & $3 \cdot 2+24 \cdot 5$ & $4 \cdot 4$ & $4 \cdot 4+24 \cdot 5$ \\
& $(n=143)$ & $(n=27)$ & $(n=242)$ & $(n=157)$ \\
\hline Pro $^{-}$ & $34(24)$ & $10(37)$ & $199(82)$ & $65(41)$ \\
Wild type & $51(36)$ & $9(33)$ & $23(10)$ & $79(50)$ \\
Arg & $35(25)$ & $6(22)$ & 0 & $4(3)$ \\
\hline
\end{tabular}

* Wild type $=$ prototrophic; $\mathrm{Pro}^{-}=$proline requiring; $\mathrm{Arg}^{-}=$ arginine requiring.
SUSCEPTIBILITY TO ANTIBIOTICS

Strains of PPNG carrying the 4.4 megadalton plasmid were more resistant to tetracycline, streptomycin, and erythromycin (fig). In this study there was a small difference between the sensitivity to spectinomycin of PPNG strains with different plasmids. This was due, however, to five strains with high level resistance to spectinomycin $(>512 \mathrm{mg} / \mathrm{l})$ that carried the 4.4 megadalton plasmid, and serological studies suggested that these represented a single clone. ${ }^{11} \mathrm{We}$ found no low level spectinomycin resistance in any of the PPNG strains tested.

\section{Discussion}

The prevalence of PPNG strains among gonococci isolated at St Mary's Hospital has undergone dramatic changes in the past five years. Firstly the rapid increase in PPNG isolates in 1981 and 1982 together with an increase in the number of infections acquired in the United Kingdom; secondly the slowing of this process in 1983; and thirdly the fall in PPNG prevalence in 1984, a trend that continued in 1985 .

The first two changes reflect events seen at national level. Thin et al also noted the rapid increase in these strains in 1981 and 1982 at St Thomas's Hospital. ${ }^{12}$ 
TABLE V Plasmid content of proline requiring "mixed" auxotypes. Figures are numbers of isolates (\% of each plasmid type)

\begin{tabular}{|c|c|c|c|c|}
\hline \multirow[b]{2}{*}{ Auxotype* } & \multicolumn{4}{|c|}{ Plasmid content (megadaltons): } \\
\hline & $\begin{array}{l}3 \cdot 2 \\
(n=143)\end{array}$ & $\begin{array}{l}3 \cdot 2+24 \cdot 5 \\
(n=27)\end{array}$ & $\begin{array}{l}4 \cdot 4 \\
(n=242)\end{array}$ & $\begin{array}{l}4 \cdot 4+24 \cdot 5 \\
(n=157)\end{array}$ \\
\hline 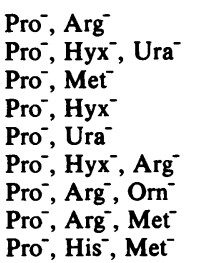 & $\begin{array}{rr}16 & (11) \\
1 & (1) \\
& \\
4 & (3) \\
1 & (1) \\
1 & (1)\end{array}$ & $\begin{array}{l}1(4) \\
1(4)\end{array}$ & $\begin{array}{l}4(2) \\
5(2) \\
1(0 \cdot 4) \\
2(1) \\
4(2) \\
1(0 \cdot 4) \\
3(1 \cdot 2)\end{array}$ & $\begin{array}{l}3(2) \\
5(3) \\
1(0 \cdot 6)\end{array}$ \\
\hline
\end{tabular}

* $\mathrm{Pro}^{-}=$proline requiring; $\mathrm{Arg}^{-}=$arginine requiring; $\mathrm{Hyx}^{-}=$hypoxanthine requiring; $\mathrm{Ura}^{-}=$uracil requiring; $\mathrm{Met}^{-}=$methionine requiring; $^{-}$ $\mathrm{Orn}^{-}=$orninthine requiring; and $\mathrm{His}^{-}=$histidine requiring.

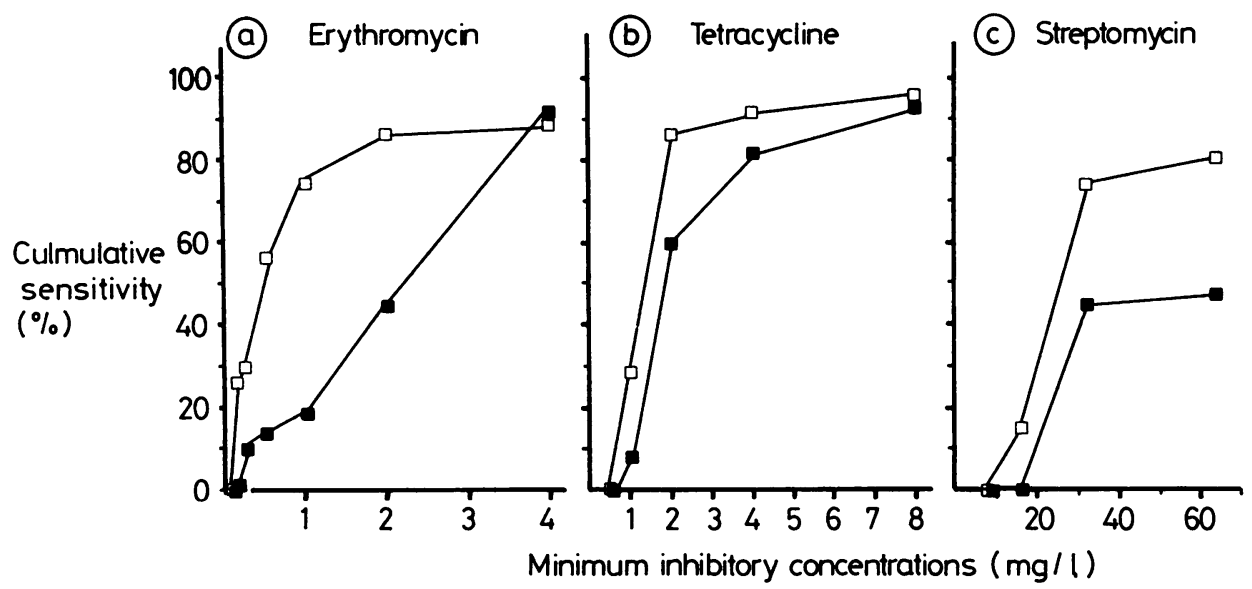

FIGURE Sensitivity of penicillinase producing Neisseria gonorrhoeae (PPNG) carrying $3 \cdot 2$ and 4.4 megadalton plasmids to three antimicrobials. PPNG strains carrying $3 \cdot 2$ megadalton plasmid $=\square ; 4 \cdot 4$ megadalton plasmid $=\square$.

Unfortunately their reported survey ended with PPNG strains isolated in 1982. Final national figures are not yet available for 1984, but provisional figures suggest that there has been a fall in PPNG isolates reported from the whole country.

Explanations for this decline could be: more effective diagnosis and treatment with penicillinase stable antibiotics, more effective contact tracing, a change in sexual activity and behaviour (caused by the advent of AIDS), or a more subtle biological change in the organism itself.

The use of more effective treatment is an attractive hypothesis to account for the changing pattern of PPNG infections at St Mary's in 1983 and 1984. In January 1983 spectinomycin was substituted for ampicillin and probenicid as first line treatment for uncomplicated anogenital gonorrhoea in women and heterosexual men attending the Praed Street Clinic. ${ }^{11}$ Though this might explain the subsequent pattern of PPNG infections if the clinic operated in isolation, it is in fact an open access clinic. In these circumstances it seems unlikely that an antibiotic policy operated by one clinic could have such a profound effect on PPNG strains. It also would not explain the similar national trend. In relatively few STD clinics has the incidence of PPNG strains reached levels that would trigger the use of first line penicillinase stable agents. ${ }^{7}$

The advent of AIDS has led to some modification of sexual activity among homosexual men. In common with others, however, we have isolated few PPNG 
strains from this group. ${ }^{13}{ }^{14}$ Ampicillin and probenicid have continued to be used for treating them. We have some evidence that PPNG strains may not survive well in the rectum, thus limiting their capacity to spread among homosexual men. We disagree to some extent with Thin et al ${ }^{12}$ about the incidence of PPNG rectal isolates in women. Because of the way "rectal" samples are taken from women at St Mary's, we are not confident that they always represent true colonisation or infection of rectal mucosa as opposed to perianal and anal contamination from the genital tract.

Contact tracing undoubtedly plays an important part in controlling infections with PPNG strains. It may be that contact tracing has become more effective in recent years. It is difficult to assess this, however, and the increase in infections from prostitutes and casual contacts in London has made contact tracing more difficult. ${ }^{12}$

The PPNG strains isolated that carry a 4.4 megadalton plasmid (434 strains) have retained the characteristics of the original isolates - that is they are prototrophic or proline requiring and are moderately resistant to antimicrobial agents. Epidemiological data show that most of these infections are now indigenous and cannot be traced to South East Asia. These PPNG strains probably resulted from the transfer of the 4.4 megadalton penicillinase coding plasmid into indigenous strains.

The 24.5 megadalton conjugal plasmid was present in more than half of strains carrying the $\mathbf{4 . 4}$ megadalton plasmid that were isolated between 1978 and 1982. This conjugal plasmid is known to mobilise transfer of the 4.4 megadalton penicillinase coding plasmid both in vitro ${ }^{15}$ and in an animal model, ${ }^{16}$ and was therefore considered to be responsible at least in part for the increased prevalence of PPNG strains. In 1983 and 1984, however, there was a dramatic reversal, and strains carrying the 4.4 megadalton penicillinase coding plasmid without the conjugal plasmid became dominant, and they remain the most commonly isolated.

There are two possible explanations for the pattern of infections caused by PPNG strains carrying the 4.4 megadalton plasmid. The simplest one is that these strains are direct descendants of the original clone and have been passaged many times in the United Kingdom. Their underlying resistance to antimicrobial agents and hydrophobic molecules (unpublished data) may confer an advantage that could result in the dominance of these strains. Alternatively, the presence of the 24.5 megadalton plasmid may have initially encouraged the spread of the 4.4 megadalton penicillinase coding plasmid into indigenous gonococci, but may itself have been lost during the transfer. The chromosomal resistance to antimicrobial agents that is present in these strains could suggest that this underlying resistance needs to be present in gonococci before the 4.4 megadalton penicillinase coding plasmid can be accepted. If this is true these PPNG strains could be indigenous.

Strains of PPNG that carry the 3.2 megadalton penicillinase coding plasmid remain more sensitive to antibiotics but show a diverse pattern of auxotypes. The first strains described carrying the 3.2 megadalton plasmid required arginine for growth, and 91\% (41/ 45) of all arginine requiring strains we have isolated carried the 3.2 megadalton plasmid. These strains, therefore, show all the characteristics of the original clone. $^{5}$ Of all strains carrying the 3.2 megadalton penicillinase coding plasmid, however, $61 \%$ are either prototrophic or require proline for growth. The auxotype is thought to be genetically stable, ${ }^{17}$ and therefore the prototrophic isolates could be the result of the acquisition of chromosomal DNA by transformation, for which gonococci are known to be particularly competent. ${ }^{18}$ Proline requiring isolates could be the result of a new clone that has evolved since 1976.

Mixed auxotypes are difficult to explain, but may be the result of dissemination of both penicillinase coding plasmids into indigenous strains.

The presence of the 24.5 megadalton plasmid in $3 \cdot 2$ megadalton carrying strains was first detected in 1980 but, unlike the experience in the Netherlands where the acquisition of this plasmid resulted in a subsequent rapid increase, ${ }^{14} 19$ the incidence has remained low. The PPNG strain carrying both 3.2 and 24.5 megadalton plasmids described by Ansink-Schipper $e t$ $a l^{14}$ were mainly of one auxotype. This may indicate the spread of a clone of PPNG strains within the community rather than mobilisation of the $3 \cdot 2$ megadalton plasmid in pre-existing gonococci. We do not know why this type of spread did not occur in this country. Worldwide, PPNG strains with the $3 \cdot 2$ megadalton plasmid have not spread as widely as those carrying the 4.4 megadalton plasmid, though the conjugal plasmid is seen in association with both types. It may be that combined carriage of the 24.5 megadalton plasmid and 3.2 megadalton plasmid is unstable. Alternatively the number of strains competent to accept the 3.2 megadalton plasmid may be limited.

We have tried to follow the epidemiology of PPNG strains isolated at St Mary's Hospital by analysing plasmid content and auxotype. Many questions remain unanswered by these methods, and these may be resolved by the use of the more discriminatory serological classification described recently. ${ }^{20}$

This work was supported by grants from the North West Thames Regional Health Authority, the Joint Standing Research Committee of St Mary's Hospital, and Upjohn International. 


\section{References}

1. Phillips I. $\beta$-lactamase-producing, penicillin-resistant gonococcus. Lancet 1976;ii:656-7.

2. Ashford WA, Golash RG, Hemming VG. Penicillinaseproducing Neisseria gonorrhoeae. Lancet 1976;ii:657-8.

3. Bergstrom S, Norlander L, Norqvist A, Normark S. Contribution of a TEM-I-like beta-lactamase to pencillin resistance in Neisseria gonorrhoeae. Antimicrob Agents Chemother 1978:13:618-23.

4. Elwell LP, Roberts M, Mayer LW, Falkow S. Plasmid mediated beta-lactamase production in Neisseria gonorrhoeae. Antimicrob Agents Chemother 1977;11:528-33.

5. Perine PL, Thornsberry C, Schalla W, et al. Evidence for two distinct types of penicillinase-producing Neisseria gonorrhoeae. Lancet 1977; ii:993-5.

6. Thornsberry C, Biddle JW, Perine PL, Siegel MS. Susceptibility of Neisseria gonorrhoeae from the United States and the Far East (beta-lactamase negative and positive) to antimicrobial agents. In Immunobiology of Neisseria gonorrhoeae. Brooks GF, Gotschlich EC, Holmes KK, Saunders WD, Young FE, eds. Washington DC: American Society of Microbiology, 1978:61-7.

7. McCutchan JA, Adler MW, Berrie JRH. Penicillinase producing Neisseria gonorrhoeae in Great Britain 1977-81: alarming increase in incidence and recent development of endemic transmission. Br Med J 1982;285:337-40.

8. O'Callaghan CH, Morris A, Kirby SM, Shingler AH. Novel method for detection of beta-lactamase by using a chromogenic cephalosporin substrate. Antimicrob Agents Chemother 1972;1:283-8.

9 Birnboim HC, Doly J. A rapid alkaline extraction procedure for screening recombinant plasmid DNA. Nucleic Acids Res 1979:7:1513-23.
10. Catlin BW. Nutritional profiles for Neisseria gonorrhoeae, Neisseria meningitidis and Neisseria lactamica in chemically defined media and the use of growth requirements for gonococcal typing. J Infect Dis 1973;128:178-94.

11. Easmon CSF, Forster GE, Walker GD, Ison CA, Harris JRW, Munday PE. Spectinomycin as initial treatment for gonorrhoea. Br Med J 1984;289:1032-4.

12. Thin RN, Barlow D, Eykyn S, Phillips I. Imported penicillinase producing Neisseria gonorrhoeae becomes endemic in London British Journal of Venereal Diseases 1983;59:364-8.

13. Jaffe HW, Biddle JW, Johnson SR, Wiesner PJ. Infections due to penicillinase producing Neisseria gonorrhoeae in the United States: 1976-1980. J Infect Dis 1981;144:191-7.

14. Ansink-Schipper MC, Huikeshoven MH, Woudstra RK, et al. Epidemiology of PPNG infections in Amsterdam: analysis by auxanographic typing and plasmid characterisation. British Journal of Venereal Diseases 1984;60:23-8.

15. Roberts $\mathbf{M}, \mathbf{F a l k o w} \mathbf{S}$. Conjugal transfer of $\mathbf{R}$ plasmids in Neisseria gonorrhoeae. Nature 1977;266:630-1.

16. Roberts $\mathrm{M}, \mathrm{Falkow} \mathrm{S}$. In vivo conjugal transfer of $\mathrm{R}$ plasmids in Neisseria gonorrhoeae. Infect Immun 1979;24:982-4.

17. Catlin BW. Genetic transformation of biosynthetically defective Neisseria gonorrhoeae clinical isolates. J Bacteriol 1974;120:203-9.

18. Sparling PF, Biswas GD, Sox TE. Transformation of the gonococcus. In: Roberts R, ed. The gonococcus. New York: John Wiley \& Son, 1977:155-76.

19. van Embden JDA, van Klingeren B, Dessens-Kroon M, van Wijngaarden LJ. Emergence in the Netherlands of pencillinaseproducing gonococci carrying "Africa" plasmid in combination with transfer plasmid. Lancet $1981 ; \mathrm{i}: 938$.

20. Knapp JS, Tam MR, Nowinski RC, Holmes KK, Sandstrom EG. Serological classification of Neisseria gonorrhoeae with the use of monoclonal antibodies to gonococcal outer membrane protein I. J Infect Dis 1984;150:44-8. 